\title{
Post-acute COVID-19 syndrome and its prolonged effects: An updated systematic
} review

Dr. Jahanzeb Malik ${ }^{1}$, Dr. Syed Muhammad Jawad Zaidi ${ }^{2}$, Dr. Raafe Iqbal ${ }^{3}$, Dr. Kashif Khan ${ }^{1}$, Dr. Muhammad Ali ${ }^{1}$, Dr. Abdul Sattar Rana ${ }^{1}$, Dr. Ali Umer Waqar, Dr. Uzma Ishaq ${ }^{5}$

1 Department of Cardiology, Rawalpindi Institute of Cardiology, Rawalpindi, 46000, Pakistan

2 Department of Medicine, Rawalpindi Medical University, Rawalpindi, 46000, Pakistan

3 Department of Cardiology, Pakistan Ordinance Factories Hospital, Wah, 47040, Pakistan

4 Department of Medicine, Shifa International Hospital, Islamabad, 44000, Pakistan

5 Department of Hematology, Foundation University Medical College, Rawalpindi, 46000, Pakistan

Corresponding author: Dr. Jahanzeb Malik, Senior Registrar, Department of Cardiology, Rawalpindi Institute of Cardiology, Rawalpindi, 46000, Pakistan.

email: $\underline{\text { heartdoc86@gmail.com }}$

Competing Interests: Authors have no competing interests to declare

Funding: Authors did not receive any specific funding for this article

Author contributions: JM; concept, literature search, first draft, final draft, methodology, analysis; SMJZ; literature review, study selection, first draft; RI; first and final draft; KK; first draft, supervision, methodology; MA; literature search, first draft; ASR; first draft, analysis, literature search; AUW; first and final draft, methodology; UI; supervision, concept; final draft, analysis. 


\section{Abstract}

Objective: This systematic review aimed at estimating the demographics, clinical characteristics, and prevalence of post-acute COVID-19 symptoms in view of published literature that studied prolonged clinical manifestations after recovery from acute COVID19 infection.

Methods: After protocol setting, relevant articles were searched on various databases including PubMed, Medline, the Cumulative Index to Nursing and Allied Health Literature (CINAHL), Embase, and Web of Sciences using MeSH keywords.

Results: Out of the 153 articles reviewed, 21 articles qualified for the final analysis. The most common persistent clinical manifestations were fatigue (54.11\%), dyspnea (24.38\%), alopecia (23.21\%), hyperhidrosis (23.6\%), insomnia (25.98\%), anxiety $(17.29 \%)$, and arthralgia (16.35\%). In addition to these symptoms, new-onset hypertension, diabetes, neuropsychiatric disorders, and bladder incontinence were also reported.

Conclusion: Clinical features of post-acute COVID-19 infection can manifest even after 60 days of initial infection. Multidisciplinary care along with regular follow-up must be provided to such patients. 


\section{Introduction}

Severe acute respiratory syndrome coronavirus 2 (SARS-COV-2) presented as clustered cases of atypical pneumonia in the city of Wuhan in the Hubei province of China. In March 2020, coronavirus disease 2019 (COVID-19) was declared as a pandemic by World Health Organization (WHO) and since then approximately 148 million people have been infected with the virus [1]. There is a wellestablished pool of scientific knowledge about the acute effects of COVID-19 and unprecedented efforts of the scientific community have now shifted towards the long-lasting sequelae of the disease, the real-world effects of which are yet to be seen [2-5].

Prolonged symptoms and signs are being reported in observational studies and case reports every day. Although such symptoms are usually experienced in survivors of critical illness, the post-acute effects of COVID-19 are equally being reported in patients with mild severity of disease who do not require hospitalization [6,7]. No established randomized controlled trials have assessed predictors of post-acute COVID-19 and many observational studies are underpowered with a small sample size to produce a significant effect model and a pooled prevalence on a global scale. Therefore, this systematic review was conducted for published research articles to estimate the incidence of abnormal manifestations after recovery from the acute COVID-19.

\section{Methods}

\section{Protocol development and selection criteria}


A protocol for the selection of articles and carrying out the systematic review of the literature was made after a consensus among the authors and subject experts but it was not deposited in a registry. Data was collected after protocol approval from the ethical review board of Foundation University Medical College (ID\#FFH/ADC/021/21).

\section{Search strategy and data extraction (selection and coding)}

The main databases used for study selection were PubMed and Medline through LitCOVID [8], the Cumulative Index to Nursing and Allied Health Literature (CINAHL), Embase, and Web of Science. Articles published before 1st May 2021 were included in the search. We included randomized clinical trials, observational, cross-sectional, and cohort studies which were in the English language, and peer-reviewed published articles that reported signs and symptoms after at least two weeks from the recovery of acute COVID-19. Only studies with more than 50 participants were included. Post-acute COVID-19 syndrome was defined as symptomatology after two weeks of recovery from COVID-19. Pre-prints, case reports, editorials, and data notes were excluded. After the initial search and removal of duplicates, all the search was imported on EndNote version 20 (Clarivate Analytics ${ }^{\mathrm{TM}}$ ). All the screening and inclusion of the articles were conducted by two independent reviewers (ASR, SMJZ) blinded to each other's decisions. Once the initial screening was finished, all the included studies were referenced in Mendeley. The two reviewers (ASR, SMJZ) reviewed full texts for final inclusion. Where there was a dispute, a third reviewer (MA) resolved it between them. The descriptive variables extracted were country, setting, follow-up time, sample size, mean age and percentage of gender, outcomes, symptoms, and signs, and names used for post-acute COVID-19 syndrome. 
The search terms used in the search strategy were as follows: ((("long-haul” coronavirus disease OR post-acute COVID-19 OR “convalescent" COVID-19) OR prolonged coronavirus infection OR coronavirus disease [Mesh]) OR "severe acute respiratory syndrome coronavirus 2" chronic disease [Supplementary Concept]) OR recurrent OR lingering OR complications of "COVID-19" [Mesh] OR "betacoronavirus" [Mesh])) AND 2019/12 [PDAT]: 2030 [PDAT]))). The systematic review followed the Preferred Reporting Items for Systematic Reviewers and Meta-analysis (PRISMA) guidelines [9] and the PRISMA flowchart is demonstrated in Figure 1.

\section{Risk of bias assessment}

All included articles were assessed using the National Institute of Health quality assessment tool for clinical studies and NewcastleOttawa Scale (NOS) [10]. Scales are provided as supplementary resources 1 and $\mathbf{2}$. Table $\mathbf{1}$ enumerates the quality status of the included studies.

\section{Strategy for data synthesis}

For statistical analysis, Statistical Package for the Social Sciences (SPSS) version 26 (IBM Corp. Armonk, NY, USA) was used, and based on the distribution of quantitative variables, they were expressed as mean \pm standard deviation (SD) or median and interquartile range (IQR). Qualitative variables were presented as frequency (n) and percentages (\%).

\section{Results}


A total of 21,741 titles and abstracts were screened for this review. Of these, 153 full texts were reviewed and according to the review protocol, 56 were excluded because of inappropriate sample size, 47 presented acute COVID-19 symptoms, 23 were case series, and 6 excluded as data notes. A total of 21 studies were included for final analysis and review and their general characteristics are shown in Table 2. Many studies assessed a specific long-term symptom after COVID-19 recovery and the PRISMA flowchart for study selection is presented in Figure 1. A total of 10 studies were from Europe and three from the United States. Others were from Mexico, Saudi Arabia, China, Australia, and Bangladesh. All studies included were on either previously hospitalized or non-hospitalized patients, and most of them had mild, moderate, and severe states of COVID-19 patients. Total follow-up time was more than one month in the majority of the studies and the number of the patient cohort was 54,730 participants with a median age of 54 years. Except for two studies, there was no stratification among gender differences between post-COVID-19 symptoms.

The general quality of the studies was assessed using the NIH quality assessment tool and Newcastle-Ottawa scale for observational studies and except one, all studies were graded in at least fair quality articles (Table 1). There were 35 post-acute symptoms and signs presented in the study cohort of these articles. They are stratified in Table 3. The most common manifestations were fatigue (54.11\%), dyspnea (24.38\%), alopecia (23.21\%), hyperhidrosis (23.6\%), insomnia (25.98\%), anxiety (17.29\%), and arthralgia (16.35\%). Thirteen studies reported fatigue and anosmia, 15 dyspnea, 12 chest pain, and 11 non-productive coughs, and 5 studies showed more than one symptom. Apart from constitutional symptoms of COVID-19, personality and sleep disorders, bladder and bowel incontinence, new-onset hypertension, and diabetes were also seen in the included studies.

\section{Discussion}


The most important pathophysiological mechanism in acute COVID-19 is direct viral toxicity leading to endothelial damage and microvascular injury. This can cause immune system dysregulation and hyperinflammatory states, hypercoagulability, and downregulation of the angiotensin-converting enzyme 2 (ACE2) pathway [11]. In contrast to this, the post-acute effects of COVID-19 are an overlap of phylogenetic similarities with SARS-COV-1 and Middle-Eastern respiratory syndrome (MERS) viruses [12]. However, SARS-COV-2 has a higher affinity for ACE2 compared with SARS-COV-1, and this mechanism may be the contributing factor in the widespread transmission of SARS-COV-2. Furthermore, potential mechanisms behind post-acute symptoms and signs in COVID-19 recovered patients seem multifactorial: the pathophysiologic changes caused by the virus, inflammatory and immunemediated cell damage, and sequelae of recovery from critical illness [13].

This systematic review demonstrated that $68 \%$ of patients have at least one post-acute symptom after recovery from COVID-19. A total of 21 studies were included in this review which fulfilled our inclusion criteria and overall 35 signs and symptoms of post-acute COVID-19 were identified in this cohort of patients (Table 3). The most common symptoms were fatigue, dyspnea, hyperhidrosis, dementia, depression, alopecia, and cough. The majority of presenting symptoms or signs were similar to the acute presentation of COVID-19. However, a possibility remains for other effects to be identified later on in this pandemic. In the following discussion, we will elaborate on the most common symptoms and signs of post-acute COVID-19 to understand each disease in more detail.

Overall, the most common symptom among all the included patients was the feeling of tiredness or fatigue $(54.11 \%)$ [6,7,14-18]. It was present after three months' follow-up in critical COVID-19 patients admitted to intensive care units (ICUs) [15]. This phenomenon has been established in survivors of critical illness (post-ICU syndrome), even after years of recovery, where half the 
patients report symptoms of chronic fatigue syndrome, including incapacitating fatigue, generalized body pain, neurocognitive disturbances, insomnia, and increased sympathetic drive [19]. Viruses like Epstein-Barr virus, cytomegalovirus, and herpes virus have been implicated in causing chronic fatigue syndrome and this review adds SARS-COV-2 as the causative agent of chronic fatigue $[20]$.

Neuropsychiatric symptoms are also reported in some studies, including headache, insomnia, anxiety, depression, bladder and bowel incontinence, ageusia, migraine, and dementia [6,16,21-24]. Similar to chronic fatigue syndrome, the etiology, and pathophysiology of neuropsychiatric symptoms in COVID-19 are multifactorial and unclear. In a cohort of 355 patients in Bangladesh, and 143 patients in Italy, a cumulative $63 \%$ of the patients were screened positive in at least one of the domains evaluated for neuropsychiatric sequelae (depression, anxiety, insomnia, obsessive-compulsive disorders, etc.) [6,14]. Clinical depression and anxiety were reported in approximately $17 \%$ of patients following COVID-19 [6]. Memory loss in the form of dementia and ageusia is also reported in a few studies, including cognitive impairment with or without fluctuations [25]. All these symptoms could be related to the social stigma of contracting a potentially fatal illness, some effects of sedatives in critical COVID-19 patients with delirium, and hypercoagulability leading to cerebrovascular disease. In addition, post-recovery sleep disturbances can also precipitate psychiatric disorders [26]. Mental health assessment and mental health attention models are very important in the post-acute COVID-19 stage, as they can contribute to a better quality of life in this cohort. Telogen effluvium and alopecia are also reported in three studies, which is defined as temporary hair loss due to excessive shedding of Telogen hair after COVID-19. Although self-limiting, this condition can cause emotional distress in many patients [27]. 
Dyspnea (24.38\%) and cough (17.17\%) were the most prominent pulmonary symptoms in this review [28]. Several studies have demonstrated persistent high resolution computed tomography (HRCT) lung abnormalities after 60 days from the initial presentation [29]. In addition, previous studies have exhibited lung dysfunction in more than $50 \%$ of the patients compared to our study cohort [7,30]. A decreased diffusion capacity due to loss of lung volume is the most commonly reported pathophysiologic impairment in post-acute effects of COVID-19, which is directly related to the severity of acute illness [31,32]. This observation is consistent with SARS and MERS and seems to be the contributing factor in long-term pulmonary sequelae of COVID-19. There is the viraldependent invasion of endothelial-epithelial barrier causing infiltration of monocytes and macrophages, leading to extravasation of protein-rich exudate filling the alveolar space. This is similar to acute respiratory distress syndrome (ARDS) [33]. There are reports of pulmonary vascular micro and macrothrombosis in $20 \%$ of the patients with critical COVID-19 pneumonia and the severity of the endothelial injury and widespread microangiopathy seen on lung histopathology is greater than that seen in ARDS from other viruses $[34,35]$.

Several other constitutional symptoms are demonstrated in this review [36-41]. The most important of them are weight loss, new-onset diabetes and hypertension, expectoration, blurred vision, and dry eyes. Chest pain is reported in up to 10\% of COVID-19 survivors at 60 days follow up, while ongoing palpitations were reported in 8.53\% at 6-months follow up. Apart from acute coronary syndrome (ACS) and myocarditis, an increased incidence of takotsubo cardiomyopathy is being reported in this pandemic compared with the pre-pandemic period (7.8\% vs. $1.5 \%$, respectively) [42]. Mechanisms contributing to cardiovascular sequelae in post-acute COVID-19 
seem to be downregulation of ACE2 and renin-angiotensin-aldosterone system (RAAS), cytokine storm-related deterioration of myocardial integrity, pericarditis, and arrhythmias [43].

This systematic review had several limitations. One is the small number of studies with underpowered sample size, creating a potential bias and variation in defined outcomes leading to the heterogeneity of the results. Many studies used a self-reporting method which can produce an interobserver bias and almost all studies enrolled COVID-19 patients in mild, moderate, and severe disease category with variable follow-up times references. This can produce heterogeneous results. There was a predefined assessment of symptoms in every study assessed, which can lead to unreported outcomes. One other limitation is that there is no definition of the effect of one severity of COVID-19 and its associated symptoms. A critical illness survivor can have prolonged symptoms while a patient with mild disease can recover early from the same problem. Hence, there is a need for prospective studies to determine if the post-acute COVID19 effects are a continuation of SARS-COV-2 or complications of premorbid conditions.

\section{Conclusion}

The multiorgan sequelae of SARS-COV-2 infection beyond the acute infection are increasingly being recognized with an increasing clinical experience and pool of data becoming available rapidly on COVID-19. This updated systematic review of 21 studies and 54,730 patients is the largest cohort of patients with post-acute effects of COVID-19 evaluated to date. It demonstrated that post-acute effects of COVID-19 can persist even at six months and from the clinical point of view, medical professionals should look for the symptoms and signs in patients recovered from COVID-19. Necessary future research includes stratification of these post-acute effects with gender, age, and comorbid conditions in acute, subacute, and chronic phases of the disease. This will lead to a better 
understanding of the delayed sequelae of COVID-19. Through this review, it is clear that acute care of COVID-19 does not conclude at hospital discharge, and interdisciplinary care is needed for comprehensive care of these patients at homes and outpatient clinics. Hence, healthcare systems must establish dedicated COVID-19 clinics, where specialists from various disciplines can provide unanimous care.

\section{Figure 1. PRISMA flow chart}

\section{References}

1. Max Roser, Hannah Ritchie, Esteban Ortiz-Ospina and Joe Hasell (2020) - "Coronavirus Pandemic (COVID-19)". Published online at OurWorldInData.org. Retrieved from: 'https://ourworldindata.org/coronavirus' [Online Resource]

2. Malik J, Malik A, Javaid M, Zahid T, Ishaq U, Shoaib M. Thyroid function analysis in COVID-19: A retrospective study from a single center. PLoS One. 2021 Mar 30;16(3):e0249421. doi: 10.1371/journal.pone.0249421. PMID: 33784355; PMCID: PMC8009384.

3. Malik J, Javaid M, Majedi O, Ishaq U, Zahid T. Paying in Blood: A Case of Thrombocytopenia in Covid-19. Cureus. 2020 Aug 16;12(8):e9791. doi: 10.7759/cureus.9791. PMID: 32953307; PMCID: PMC7491688.

4. Malik J, Javed N, Naeem H, Sattar RA, Ikram U. COVID-19 Associated Pneumonia and Pleural Effusion Masquerading as Heart Failure in Rheumatic Heart Disease. Eur J Case Rep Intern Med. 2020 Jul 10;7(8):001842. doi: 10.12890/2020_001842. PMID: 32789145; PMCID: PMC7417058. 
5. Shafi AMA, Shaikh SA, Shirke MM, Iddawela S, Harky A. Cardiac manifestations in COVID-19 patients-A systematic review. J Card Surg. 2020 Aug;35(8):1988-2008. doi: 10.1111/jocs.14808. Epub 2020 Jul 11. PMID: 32652713; PMCID: PMC7404674.

6. Mahmud R, Rahman MM, Rassel MA, Monayem FB, Sayeed SKJB, Islam MS, et al. Post-COVID-19 syndrome among symptomatic COVID-19 patients: A prospective cohort study in a tertiary care center of Bangladesh. PLoS One. 2021 Apr 8;16(4):e0249644. doi: 10.1371/journal.pone.0249644. PMID: 33831043; PMCID: PMC8031743.

7. Huang C, Huang L, Wang Y, Li X, Ren L, Gu X, et al. 6-month consequences of COVID-19 in patients discharged from hospital: a cohort study. Lancet. 2021 Jan 16;397(10270):220-232. doi: 10.1016/S0140-6736(20)32656-8. Epub 2021 Jan 8. PMID: 33428867; PMCID: PMC7833295.

8. Chen Q, Allot A, Lu Z. LitCovid: an open database of COVID-19 literature. Nucleic Acids Res. 2021 Jan 8;49(D1):D1534-D1540. doi: 10.1093/nar/gkaa952. PMID: 33166392; PMCID: PMC7778958.

9. Shamseer L, Moher D, Clarke M, Ghersi D, Liberati A, Petticrew M, Shekelle P, Stewart LA; PRISMA-P Group. Preferred reporting items for systematic review and meta-analysis protocols (PRISMA-P) 2015: elaboration and explanation. BMJ. 2015 Jan 2;350:g7647. doi: 10.1136/bmj.g7647. Erratum in: BMJ. 2016 Jul 21;354:i4086. PMID: 25555855.

10. Ma LL, Wang YY, Yang ZH, Huang D, Weng H, Zeng XT. Methodological quality (risk of bias) assessment tools for primary and secondary medical studies: what are they and which is better? Mil Med Res. 2020 Feb 29;7(1):7. doi: 10.1186/s40779-020-00238-8. PMID: 32111253; PMCID: PMC7049186.

11. Gupta A, Madhavan MV, Sehgal K, Nair N, Mahajan S, Sehrawat TS, et al. Extrapulmonary manifestations of COVID-19. Nat Med. 2020 Jul;26(7):1017-1032. doi: 10.1038/s41591-020-0968-3. Epub 2020 Jul 10. PMID: 32651579. 
12. Hu B, Guo H, Zhou P, Shi ZL. Characteristics of SARS-CoV-2 and COVID-19. Nat Rev Microbiol. 2021 Mar;19(3):141-154. doi: 10.1038/s41579-020-00459-7. Epub 2020 Oct 6. PMID: 33024307; PMCID: PMC7537588.

13. Shang J, Ye G, Shi K, Wan Y, Luo C, Aihara H, et al. Structural basis of receptor recognition by SARS-CoV-2. Nature. 2020 May;581(7807):221-224. doi: 10.1038/s41586-020-2179-y. Epub 2020 Mar 30. PMID: 32225175; PMCID: PMC7328981.

14. Carfî A, Bernabei R, Landi F; Gemelli Against COVID-19 Post-Acute Care Study Group. Persistent Symptoms in Patients After Acute COVID-19. JAMA. 2020 Aug 11;324(6):603-605. doi: 10.1001/jama.2020.12603. PMID: 32644129; PMCID: PMC7349096.

15. Townsend L, Dowds J, O'Brien K, Sheill G, Dyer AH, O'Kelly B, et al. Persistent Poor Health Post-COVID-19 Is Not Associated with Respiratory Complications or Initial Disease Severity. Ann Am Thorac Soc. 2021 Jan 8. doi: 10.1513/AnnalsATS.202009-1175OC. Epub ahead of print. PMID: 33413026.

16. Mandal S, Barnett J, Brill SE, Brown JS, Denneny EK, Hare SS, et al. 'Long-COVID': a cross-sectional study of persisting symptoms, biomarker and imaging abnormalities following hospitalisation for COVID-19. Thorax. 2020 Nov 10:thoraxjnl-2020-215818. doi: 10.1136/thoraxjnl-2020-215818. Epub ahead of print. PMID: 33172844; PMCID: PMC7661378.

17. El Sayed S, Shokry D, Gomaa SM. Post-COVID-19 fatigue and anhedonia: A cross-sectional study and their correlation to post-recovery period. Neuropsychopharmacol Rep. 2021 Mar;41(1):50-55. doi: 10.1002/npr2.12154. Epub 2020 Dec 17. PMID: 33332756.

18. Moreno-Pérez O, Merino E, Leon-Ramirez JM, Andres M, Ramos JM, Arenas-Jiménez J, et al. Post-acute COVID-19 syndrome. Incidence and risk factors: A Mediterranean cohort study. J Infect. 2021 Mar;82(3):378-383. doi: 10.1016/j.jinf.2021.01.004. Epub 2021 Jan 12. PMID: 33450302; PMCID: PMC7802523. 
19. Moldofsky H, Patcai J. Chronic widespread musculoskeletal pain, fatigue, depression and disordered sleep in chronic post-SARS syndrome; a case-controlled study. BMC Neurol. 2011 Mar 24;11:37. doi: 10.1186/1471-2377-11-37. PMID: 21435231; PMCID: PMC3071317.

20. Wostyn P. COVID-19 and chronic fatigue syndrome: Is the worst yet to come? Med Hypotheses. 2021 Jan;146:110469. doi: 10.1016/j.mehy.2020.110469. Epub 2021 Jan 2. PMID: 33401106; PMCID: PMC7836544.

21. Chopra V, Flanders SA, O'Malley M, Malani AN, Prescott HC. Sixty-Day Outcomes Among Patients Hospitalized With COVID-19. Ann Intern Med. 2021 Apr;174(4):576-578. doi: 10.7326/M20-5661. Epub 2020 Nov 11. PMID: 33175566; PMCID: PMC7707210.

22. Halpin SJ, McIvor C, Whyatt G, Adams A, Harvey O, McLean L, et al. Postdischarge symptoms and rehabilitation needs in survivors of COVID-19 infection: A cross-sectional evaluation. J Med Virol. 2021 Feb;93(2):1013-1022. doi: 10.1002/jmv.26368. Epub 2020 Aug 17. PMID: 32729939.

23. Sudre CH, Murray B, Varsavsky T, Graham MS, Penfold RS, Bowyer RC, et al. Attributes and predictors of long COVID. Nat Med. 2021 Apr;27(4):626-631. doi: 10.1038/s41591-021-01292-y. Epub 2021 Mar 10. PMID: 33692530.

24. Taquet M, Geddes JR, Husain M, Luciano S, Harrison PJ. 6-month neurological and psychiatric outcomes in $236 \square 379$ survivors of COVID-19: a retrospective cohort study using electronic health records. Lancet Psychiatry. 2021 May;8(5):416-427. doi: 10.1016/S22150366(21)00084-5. Epub 2021 Apr 6. PMID: 33836148; PMCID: PMC8023694.

25. Rogers JP, Chesney E, Oliver D, Pollak TA, McGuire P, Fusar-Poli P, et al. Psychiatric and neuropsychiatric presentations associated with severe coronavirus infections: a systematic review and meta-analysis with comparison to the COVID-19 pandemic. Lancet Psychiatry. 2020 Jul;7(7):611-627. doi: 10.1016/S2215-0366(20)30203-0. Epub 2020 May 18. PMID: 32437679; PMCID: PMC7234781. 
26. Bacaro V, Chiabudini M, Buonanno C, De Bartolo P, Riemann D, Mancini F, et al. Insomnia in the Italian Population During Covid-19 Outbreak: A Snapshot on One Major Risk Factor for Depression and Anxiety. Front Psychiatry. 2020 Dec 15;11:579107. doi: 10.3389/fpsyt.2020.579107. PMID: 33384625; PMCID: PMC7769843.

27. Xiong Q, Xu M, Li J, Liu Y, Zhang J, Xu Y, et al. Clinical sequelae of COVID-19 survivors in Wuhan, China: a single-centre longitudinal study. Clin Microbiol Infect. 2021 Jan;27(1):89-95. doi: 10.1016/j.cmi.2020.09.023. Epub 2020 Sep 23. PMID: 32979574; PMCID: PMC7510771.

28. Carvalho-Schneider C, Laurent E, Lemaignen A, Beaufils E, Bourbao-Tournois C, Laribi S, et al. Follow-up of adults with noncritical COVID-19 two months after symptom onset. Clin Microbiol Infect. 2021 Feb;27(2):258-263. doi: 10.1016/j.cmi.2020.09.052. Epub 2020 Oct 5. PMID: 33031948; PMCID: PMC7534895.

29. Balbi M, Conti C, Imeri G, Caroli A, Surace A, Corsi A, et al. Post-discharge chest CT findings and pulmonary function tests in severe COVID-19 patients. Eur J Radiol. 2021 May;138:109676. doi: 10.1016/j.ejrad.2021.109676. Epub 2021 Mar 20. PMID: 33798931; PMCID: PMC7980523.

30. Zhao YM, Shang YM, Song WB, Li QQ, Xie H, Xu QF, et al. Follow-up study of the pulmonary function and related physiological characteristics of COVID-19 survivors three months after recovery. EClinicalMedicine. 2020 Aug;25:100463. doi: 10.1016/j.eclinm.2020.100463. Epub 2020 Jul 15. PMID: 32838236; PMCID: PMC7361108.

31. Huang Y, Tan C, Wu J, Chen M, Wang Z, Luo Let al. Impact of coronavirus disease 2019 on pulmonary function in early convalescence phase. Respir Res. 2020 Jun 29;21(1):163. doi: 10.1186/s12931-020-01429-6. PMID: 32600344; PMCID: PMC7323373. 
32. Galván-Tejada CE, Herrera-García CF, Godina-González S, Villagrana-Bañuelos KE, Amaro JDL, Herrera-García K, et al. Persistence of COVID-19 Symptoms after Recovery in Mexican Population. Int J Environ Res Public Health. 2020 Dec 14;17(24):9367. doi: 10.3390/ijerph17249367. PMID: 33327641; PMCID: PMC7765113.

33. Huppert LA, Matthay MA, Ware LB. Pathogenesis of Acute Respiratory Distress Syndrome. Semin Respir Crit Care Med. 2019 Feb;40(1):31-39. doi: 10.1055/s-0039-1683996. Epub 2019 May 6. PMID: 31060086; PMCID: PMC7060969.

34. Cui S, Chen S, Li X, Liu S, Wang F. Prevalence of venous thromboembolism in patients with severe novel coronavirus pneumonia. J Thromb Haemost. 2020 Jun;18(6):1421-1424. doi: 10.1111/jth.14830. Epub 2020 May 6. PMID: 32271988; PMCID: PMC7262324.

35. Tenforde MW, Kim SS, Lindsell CJ, Billig Rose E, Shapiro NI, Files DC, et al. Symptom Duration and Risk Factors for Delayed Return to Usual Health Among Outpatients with COVID-19 in a Multistate Health Care Systems Network - United States, March-June 2020. MMWR Morb Mortal Wkly Rep. 2020 Jul 31;69(30):993-998. doi: 10.15585/mmwr.mm6930e1. PMID: 32730238; PMCID: PMC7392393.

36. Kamal M, Abo Omirah M, Hussein A, Saeed H. Assessment and characterisation of post-COVID-19 manifestations. Int J Clin Pract. 2021 Mar;75(3):e13746. doi: 10.1111/ijcp.13746. Epub 2020 Nov 3. PMID: 32991035; PMCID: PMC7536922.

37. Garrigues E, Janvier P, Kherabi Y, Le Bot A, Hamon A, Gouze H, et al. Post-discharge persistent symptoms and health-related quality of life after hospitalization for COVID-19. J Infect. 2020 Dec;81(6):e4-e6. doi: 10.1016/j.jinf.2020.08.029. Epub 2020 Aug 25. PMID: 32853602; PMCID: PMC7445491. 
38. Horvath L, Lim JWJ, Taylor JW, Saief T, Stuart R, Rimmer J, et al. Smell and taste loss in COVID-19 patients: assessment outcomes in a Victorian population. Acta Otolaryngol. 2021 Mar;141(3):299-302. doi: 10.1080/00016489.2020.1855366. Epub 2020 Dec 12. PMID: 33307905 .

39. Arnold DT, Hamilton FW, Milne A, Morley AJ, Viner J, Attwood M, et al. Patient outcomes after hospitalisation with COVID-19 and implications for follow-up: results from a prospective UK cohort. Thorax. 2020 Dec 3;76(4):399-401. doi: 10.1136/thoraxjnl-2020216086. Epub ahead of print. PMID: 33273026; PMCID: PMC7716340.

40. Osikomaiya B, Erinoso O, Wright KO, Odusola AO, Thomas B, Adeyemi O, et al. 'Long COVID': persistent COVID-19 symptoms in survivors managed in Lagos State, Nigeria. BMC Infect Dis. 2021 Mar 25;21(1):304. doi: 10.1186/s12879-020-05716-x. PMID: 33765941; PMCID: PMC7993075.

41. Leth S, Gunst JD, Mathiasen V, Hansen K, Søgaard O, Østergaard L, et al. Persistent Symptoms in Patients Recovering From COVID-19 in Denmark. Open Forum Infect Dis. 2021 Jan 29;8(4):ofab042. doi: 10.1093/ofid/ofab042. PMID: 33875970; PMCID: PMC7928683.

42. Jabri A, Kalra A, Kumar A, Alameh A, Adroja S, Bashir H, et al. Incidence of Stress Cardiomyopathy During the Coronavirus Disease 2019 Pandemic. JAMA Netw Open. 2020 Jul 1;3(7):e2014780. doi: 10.1001/jamanetworkopen.2020.14780. PMID: 32644140; PMCID: PMC7348683.

43. Liu PP, Blet A, Smyth D, Li H. The Science Underlying COVID-19: Implications for the Cardiovascular System. Circulation. 2020 Jul 7;142(1):68-78. doi: 10.1161/CIRCULATIONAHA.120.047549. Epub 2020 Apr 15. PMID: 32293910. 
Tables

\begin{tabular}{|l|l|l|}
\hline Judgement & \multicolumn{2}{|l|}{ Clinical studies } \\
& NIH quality & Newcastle-Ottawa \\
& $\begin{array}{l}|c| \\
\text { assessment tool; n }\end{array}$ & scale; n (\%) \\
\hline Good & $8(38 \%)$ & $10(47.61 \%)$ \\
\hline Fair & $12(57.14 \%)$ & $11(52.38 \%)$ \\
\hline Poor & $1(4.76 \%)$ & 0 \\
\hline
\end{tabular}


Table 1. Quality assessment of included articles according to NIH quality assessment tool and Newcastle-Ottawa scale for observational studies.

\begin{tabular}{|c|c|c|c|c|c|c|c|c|c|}
\hline \# & Author [ref] & Country & Setting & $\begin{array}{l}\text { Follow-up } \\
\text { (Mean) }\end{array}$ & Study participants & $\begin{array}{l}\text { Sample size } \\
\text { (n) }\end{array}$ & $\begin{array}{l}\text { Age; mean } \pm \\
\text { SD/median } \\
(I Q R)\end{array}$ & Males; \% & Outcome variables \\
\hline
\end{tabular}




\begin{tabular}{|c|c|c|c|c|c|c|c|c|c|}
\hline & & & & of symptoms & $\begin{array}{l}\text { fever for } 3 \text { consecutive } \\
\text { days, improvement } \\
\text { in symptoms, and } 2 \\
\text { negative test results for } \\
\text { SARS-CoV-2 virus } 24 \\
\text { hours apart) }\end{array}$ & & & & $\begin{array}{l}\text { length of hospital stay, } \\
\text { Number of persistent } \\
\text { symptoms. Fever, fatigue, } \\
\text { red eyes, chest pain, cough, } \\
\text { anosmia, dysgeusia, } \\
\text { myalgia, diarrhea }\end{array}$ \\
\hline 2 & $\begin{array}{l}\text { Mandal et al. } \\
{[16]}\end{array}$ & $\begin{array}{l}\text { London, United } \\
\text { Kingdom }\end{array}$ & $\begin{array}{l}\text { Multi-centric (3 } \\
\text { hospitals) }\end{array}$ & $\begin{array}{l}\text { 4-6 week after } \\
\text { discharge }\end{array}$ & $\begin{array}{l}\text { Patients } \\
\text { with abnormal blood } \\
\text { tests or imaging at } \\
\text { discharge. }\end{array}$ & 384 & $59.9 \pm 16.1$ & $62 \%$ & $\begin{array}{l}\text { Symptom persistence } \\
\text { including breathlessness, } \\
\text { cough, fatigue, and, poor } \\
\text { sleep quality. Laboratory } \\
\text { parameters including TLC, } \\
\text { platlet count, Lymphocyte } \\
\text { count, D dimers, LFTs, and } \\
\text { CRP levels }\end{array}$ \\
\hline 3 & Chopra et al.[21] & United States & $\begin{array}{l}\text { Multi-centric (38 } \\
\text { hospitals) }\end{array}$ & $\begin{array}{l}60 \text { days post } \\
\text { discharge }\end{array}$ & $\begin{array}{l}\text { ICU/Hospitalized } \\
\text { COVID-19 patients } \\
\text { discharged between } 16 \\
\text { March and } 1 \text { July } 2020 \\
\text { at } 38 \text { hospitals. }\end{array}$ & 488 & $62(50-72)$ years & $51.8 \%$ & $\begin{array}{l}\text { Mortality and } \\
\text { rehospitalization, Primary } \\
\text { care follow-up, } \\
\text { New/worsened symptoms, } \\
\text { Return to normal activity, } \\
\text { Emotional impact, } \\
\text { Financial loss/impact }\end{array}$ \\
\hline 4 & $\begin{array}{l}\text { El Sayed et } \\
\text { al.[17] }\end{array}$ & Saudi Arabia & Single centered & $\begin{array}{l}\text { After } \\
\text { discharge. } \\
\text { Duration not } \\
\text { mentioned }\end{array}$ & $\begin{array}{l}\text { Patients of COVID-19 } \\
\text { after } 2 \text { consecutive } \\
\text { negative PCR tests } \\
\text { attending pulmonology }\end{array}$ & 200 & $36.58 \pm 9.85$ & $\begin{array}{l}114 \text { out of } \\
200(57 \%)\end{array}$ & $\begin{array}{l}\text { Assessment of fatigue and } \\
\text { anhedonia using validated } \\
\text { scales. }\end{array}$ \\
\hline
\end{tabular}




\begin{tabular}{|c|c|c|c|c|c|c|c|c|c|}
\hline & & & & & $\begin{array}{l}\text { clinic for } \\
\text { follow-up }\end{array}$ & & & & \\
\hline 5 & $\begin{array}{l}\text { Mahmud et al. } \\
\text { [6] }\end{array}$ & $\begin{array}{l}\text { Dhaka, } \\
\text { Bangladesh }\end{array}$ & Single centered & $\begin{array}{l}\text { One month } \\
\text { after discharge }\end{array}$ & $\begin{array}{l}\text { Discharged COVID-19 } \\
\text { patients }\end{array}$ & 355 & $39.8 \pm 13.4$ & $\begin{array}{l}207 \text { out of } \\
355(58.3 \%)\end{array}$ & $\begin{array}{l}\text { The frequency and interval } \\
\text { of a spectrum of post } \\
\text { COVID-19 symptoms were } \\
\text { assessed. These include } \\
\text { post viral fatigue, persistent } \\
\text { cough, insomnia, Circadian } \\
\text { rhythm sleep disorders, } \\
\text { headache, vertigo, Post- } \\
\text { exertional dyspnea, rash, } \\
\text { pneumonia, restless leg } \\
\text { syndrome, chest pain, } \\
\text { Adjustment disorder, Nasal } \\
\text { blockage, Excessive } \\
\text { sweating, Disturbance of } \\
\text { memory, New-onset } \\
\text { diabetes or hypertension, } \\
\text { myalgias, and Precipitation } \\
\text { of gout }\end{array}$ \\
\hline 6 & $\begin{array}{l}\text { Carvalho- } \\
\text { Schneider et al. } \\
{[28]}\end{array}$ & France & Single centered & $\begin{array}{l}\text { Two months } \\
\text { after onset of } \\
\text { symptoms. }\end{array}$ & $\begin{array}{l}\text { Post COVID-19 patients } \\
\text { with or without clinical } \\
\text { signs of pneumonia but } \\
\text { without a } \\
\text { need for oxygen therapy }\end{array}$ & 150 & $49 \pm 15$ years & $44 \%$ & $\begin{array}{l}\text { Persisting symptoms at Day } \\
30 \text { and } 60 \text { which included } \\
\text { Fever, dyspnea, chest pain, } \\
\text { abnormal auscultation, flu- } \\
\text { like symptoms, digestive }\end{array}$ \\
\hline
\end{tabular}




\begin{tabular}{|c|c|c|c|c|c|c|c|c|c|}
\hline & & & & & (mild/moderate disease) & & & & $\begin{array}{l}\text { disorders, weight loss, } \\
\text { anosmia, palpitations, } \\
\text { arthralgia, cutaneous rashes }\end{array}$ \\
\hline 7 & Marwa et al. [36] & Egypt & Single centered & $\begin{array}{l}\text { Duration not } \\
\text { mentioned }\end{array}$ & $\begin{array}{l}\text { Patients recovered from } \\
\text { COVID-19 }\end{array}$ & 287 & $32.3 \pm 8.5$ & $\begin{array}{l}103 \text { out of } \\
287(35.8 \%)\end{array}$ & $\begin{array}{l}\text { Fatigue, anxiety, joint pain, } \\
\text { continuous headache, chest } \\
\text { pain, dementia, depression, } \\
\text { dyspnea, blurred vision, } \\
\text { tinnitus, intermittent fever, } \\
\text { obsessive compulsive } \\
\text { disorder }\end{array}$ \\
\hline 8 & $\begin{array}{l}\text { Galván-Tejada et } \\
\text { al. [32] }\end{array}$ & Mexico & Multi centeric & $\begin{array}{l}\text { Duration not } \\
\text { mentioned }\end{array}$ & $\begin{array}{l}\text { Cases: Patients who had } \\
\text { a laboratory-confirmed } \\
\text { diagnosis of SARS- } \\
\text { CoV-2, and in whom at } \\
\text { least fourteen days have } \\
\text { passed } \\
\text { since the appearance of } \\
\text { symptoms. } \\
\text { Controls: Patients with } \\
\text { no laboratory or } \\
\text { clinically proven } \\
\text { COVID-19 infection }\end{array}$ & $\begin{array}{l}\text { 141 cases } \\
\text { and } 78 \\
\text { controls. } \\
\text { (Total 218) }\end{array}$ & $\begin{array}{l}\text { Means of } 39.14 \\
\text { years for females } \\
\text { and } 39.01 \text { for } \\
\text { males } \\
\text { respectively }\end{array}$ & $49 \%$ & $\begin{array}{l}\text { Fever, myalgia, rhinorrhea } \\
\text { or coryza, asthenia, cough, } \\
\text { cephalgia, red eyes, } \\
\text { odynophagia, nausea, vomit } \\
\text { or } \\
\text { diarrhea, anosmia or } \\
\text { dysgeusia, stomach pain or } \\
\text { discomfort, dyspnea, chills }\end{array}$ \\
\hline 9 & $\begin{array}{l}\text { Moreno-Pérez et } \\
\text { al.[18] }\end{array}$ & Spain & Single centric & $\begin{array}{l}\text { 10-14 weeks } \\
\text { after discharge }\end{array}$ & $\begin{array}{l}\text { Hospitalized Patients } \\
\text { who had laboratory } \\
\text { proven SARS-COV-2 }\end{array}$ & 277 & $56.0(42.0-67.5)$ & $52.7 \%$ & $\begin{array}{l}\text { Post- COVID syndrome. } \\
\text { These include pneumonia, } \\
\text { fatigue, anosmia, dyspnea, }\end{array}$ \\
\hline
\end{tabular}




\begin{tabular}{|c|c|c|c|c|c|c|c|c|c|}
\hline & & & & & & & & & $\begin{array}{l}\text { persistent cough, headache } \\
\text { fever, diarrhea, neurological } \\
\text { symptoms, and laboratory } \\
\text { features }\end{array}$ \\
\hline 10 & Halpin et al. [22] & United Kingdom & Single centered & $\begin{array}{l}4 \text { to } 8 \text { weeks } \\
\text { after discharge }\end{array}$ & $\begin{array}{l}\text { Hospitalized Patients } \\
\text { who had laboratory } \\
\text { proven SARS-COV-2 } \\
\text { and were discharged } \\
\text { from hospital }\end{array}$ & 100 & $\begin{array}{l}\text { For } \quad \text { ward } \\
\text { patients: } \quad 70.5 \\
(20 \square 93) \quad \text { For } \\
\text { ICU patients: } \\
58.5(34 \square 84)\end{array}$ & $54 \%$ & $\begin{array}{l}\text { Fatigue, Breathlessness, } \\
\text { Neuropsychological } \\
\text { symptoms, Speech and } \\
\text { swallowing problems, } \\
\text { weight loss/gain, } \\
\text { bowel/bladder incontinence, } \\
\text { Perceived health, quality of } \\
\text { life, and Vocation change } \\
\text { since COVID } \square 19 \text { illness. }\end{array}$ \\
\hline 11 & Huang et al [7] & China & Single centered & $\begin{array}{l}\text { Median follow } \\
\text { up days: } 186 \\
(175-199) \text { days }\end{array}$ & $\begin{array}{l}\text { patients with laboratory } \\
\text { confirmed COVID-19 } \\
\text { who were } \\
\text { discharged between Jan } \\
\text { 7, and } \\
\text { May 29, } 2020\end{array}$ & 1733 & $57 \cdot 0(47 \cdot 0-65 \cdot 0)$ & $52 \%$ & $\begin{array}{l}\text { Fatigues, } \\
\text { problems, hairloss, } \\
\text { anosmia, palpitations, joint } \\
\text { pain, decreased appetite, } \\
\text { taste disorder, chest pain, } \\
\text { myalgias, rashes, } \\
\text { swallowing difficulty, Low } \\
\text { grade fever, eGFR, and } \\
\text { quality of life }\end{array}$ \\
\hline 12 & Xiong et al. [27] & China & Single centered & $\begin{array}{l}\text { Follow up time } \\
\text { of more than } 3 \\
\text { months for }\end{array}$ & $\begin{array}{l}\text { All COVID-19 survivors } \\
\text { who were diagnosed } \\
\text { with } \quad \text { COVID-19 }\end{array}$ & 538 & $\begin{array}{l}52.0 \\
(41.0-62.0) \text { years }\end{array}$ & $\begin{array}{l}245 \text { out of } \\
538(45.5 \%)\end{array}$ & $\begin{array}{l}\text { Fatigue, swelling, myalgias, } \\
\text { arthralgia, chills, limb } \\
\text { edema, dizziness, chest }\end{array}$ \\
\hline
\end{tabular}




\begin{tabular}{|c|c|c|c|c|c|c|c|c|c|}
\hline & & & & each survivor & $\begin{array}{l}\text { according to } \\
\text { WHO interim guidance } \\
\text { and were } \\
\text { discharged from the } \\
\text { hospital by } 1 \text { March } \\
2020\end{array}$ & & & & $\begin{array}{l}\text { pain, post activity polypnea, } \\
\text { cough sputum, throat pain, } \\
\text { palpitations, discontinuous } \\
\text { flushing, new onset } \\
\text { hypertension, depression, } \\
\text { anxiety, and alopecia }\end{array}$ \\
\hline 13 & $\begin{array}{l}\text { Tenforde et al. } \\
\text { [35] }\end{array}$ & United States & Single centered & $\begin{array}{l}\text { 14-21 days } \\
\text { after the test } \\
\text { date }\end{array}$ & $\begin{array}{l}\text { adults aged } \geq 18 \text { years } \\
\text { who had a first positive } \\
\text { RT-PCR test for SARS- } \\
\text { CoV-2, and reported } \\
\text { persistence COVID-19 } \\
\text { symptoms }\end{array}$ & 270 & $\begin{array}{l}26 \% \text { patients } \\
\text { aged between } \\
18-34 \text { years, } \\
32 \% \text { aged } \\
\text { between } \\
35-49 \text { years, and } \\
47 \% \text { aged } \geq 50 \\
\text { years }\end{array}$ & $\begin{array}{l}130 \text { out of } \\
270(48.14 \%)\end{array}$ & $\begin{array}{l}\text { Risk Factors for Delayed } \\
\text { Return to Usual Health } \\
\text { Among COVID-19 patients } \\
\text { were evaluated. The } \\
\text { outcome variables included } \\
\text { age, comorbids, ethinicity, } \\
\text { gender }\end{array}$ \\
\hline 14 & Taquet et al. [24] & United States & $\begin{array}{l}\text { Multicentric, } \\
\text { electronic records }\end{array}$ & 14-90 days & $\begin{array}{ll}\text { Discharged } & \text { COVID-19 } \\
\text { patients } & \text { with no } \\
\text { previous } & \text { psychiatric } \\
\text { illness } & \end{array}$ & 44,779 & $\begin{array}{l}49.3 \\
(19.2)\end{array}$ & 45.1 & $\begin{array}{l}\text { New onset psychiatric } \\
\text { illness } \\
\text { disorders psychotic, } \\
\text { insomnia, mood disorders } \\
\text { (depressive episodes) } \\
\text { anxiety disorders (PTSD, } \\
\text { panic disorder, adjustment } \\
\text { disorder and generalized } \\
\text { anxiety disorder). }\end{array}$ \\
\hline 15 & $\begin{array}{l}\text { Townsend et } \\
\text { al.[15] }\end{array}$ & Ireland & $\begin{array}{l}\text { Single centered, } \\
\text { outpatient clinic }\end{array}$ & $\begin{array}{l}56 \text { days to } \\
12 \text { weeks }\end{array}$ & $\begin{array}{l}\text { Mild, moderate } \\
\text { Symptomatic patients }\end{array}$ & 128 & $49.5 \pm 15$ years & $46.1 \%$ & Persistent fatigue \\
\hline
\end{tabular}




\begin{tabular}{|c|c|c|c|c|c|c|c|c|c|}
\hline & & & & & $\begin{array}{ll}\text { and } & \text { Hospitalized } \\
\text { patients } & \end{array}$ & & & & \\
\hline 16 & $\begin{array}{l}\text { Garrigues et al. } \\
\text { [37] }\end{array}$ & France & Single centered & 110.9 days & $\begin{array}{l}\text { Discharged COVID-19 } \\
\text { patients who were } \\
\text { Hospitalized in ward or } \\
\text { ICU }\end{array}$ & 120 & $63.2(15.7)$ years & $\begin{array}{l}75 \text { out of } 120 \\
(62.5 \%)\end{array}$ & $\begin{array}{l}\text { Cough, chest pain, fatigue, } \\
\text { dyspnea, ageusia, anosmia, } \\
\text { hair loss, attention disorder, } \\
\text { memory loss, sleep } \\
\text { disorder }\end{array}$ \\
\hline 17 & $\begin{array}{l}\text { Horvath et al. } \\
{[38]}\end{array}$ & Australia & $\begin{array}{l}\text { Multicentric, } \\
\text { computed records }\end{array}$ & 83 days & $\begin{array}{l}\text { Discharged COVID-19 } \\
\text { patients with mild to } \\
\text { moderate } \\
\text { intensity }\end{array}$ & 102 & $45(17-87)$ years & $40 \%$ & $\begin{array}{l}\text { Smell reduction, taste } \\
\text { change, cough, fever, } \\
\text { headaches, worsening nasal } \\
\text { blockage, runny nose, } \\
\text { fatigue, sore throat. }\end{array}$ \\
\hline 18 & Arnold et al.[39] & United Kingdom & Single centered & 28 days & $\begin{array}{l}\text { patients ( } \geq \text { 18years } \\
\text { of age) admitted with } \\
\text { COVID- } 1\end{array}$ & 110 & $60(46-73)$ years & $56 \%$ & $\begin{array}{l}\text { Fever, cough arthralgia, } \\
\text { myalgias, chest pain, } \\
\text { anosmia, diarrhea, } \\
\text { abdominal pain, headache, } \\
\text { insomnia, deranged blood } \\
\text { tests, spirometry and chest } \\
\text { C ray }\end{array}$ \\
\hline 19 & $\begin{array}{l}\text { Osikomaiya et al. } \\
\text { [40] }\end{array}$ & Nigeria & Multi- centered & $\begin{array}{l}\text { Two weeks } \\
\text { after discharge }\end{array}$ & $\begin{array}{l}\text { Discharged COVID-19 } \\
\text { patients who were } \\
\text { Hospitalized in ward or } \\
\text { ICU }\end{array}$ & 274 & $41.8 \pm 11.8$ years & $\begin{array}{l}181 \text { out of } \\
274(66.1 \%)\end{array}$ & $\begin{array}{l}\text { Fever, fatigue, weight loss, } \\
\text { malaise, cough, dyspnea, } \\
\text { chest pain, anosmia, loss of } \\
\text { appetite, dizziness, } \\
\text { palpitations, insomnia } \\
\text { vertigo, dysgeusia }\end{array}$ \\
\hline
\end{tabular}




\begin{tabular}{|c|c|c|c|c|c|c|c|c|c|}
\hline 20 & Leth et al. [41] & Denmark & Single centered & 12-week & $\begin{array}{l}\text { Hospitalized COVID-19 } \\
\text { that were discharged } \\
\text { after negative PCR }\end{array}$ & 71 patients & $58(48-73)$ & $43 \%$ & $\begin{array}{l}\text { Difficulty in concentration, } \\
\text { paresthesia's, headache, } \\
\text { anosmia, taste impairment, } \\
\text { cough dyspnea, } \\
\text { expectoration, sore throat, }\end{array}$ \\
\hline 21 & Sudre et al.[23] & United Kingdom & Multi-center & 3 months & $\begin{array}{l}\text { Mobile health app users } \\
\text { with PCR positive } \\
\text { COVID-19 } \\
\text { patients/negative } \\
\text { matched controls }\end{array}$ & 4,182 & $44(28,56)$ & $28.5 \%$ & $\begin{array}{l}\text { Number of symptoms, } \\
\text { duration of symptoms, } \\
\text { quality of life, }\end{array}$ \\
\hline
\end{tabular}

Table 2. General article characteristics and study population. Standard deviation (SD), interquartile range (IQR)

\begin{tabular}{|l|l|l|l|l|}
\hline Clinical characteristics of post- & Studies (n) & Number of patients & Total number & of \\
acute COVID-19 & & Prevalence; & $\%$ \\
\hline Fatigue & 13 & 2412 & 4457 & $54.11 \%$ \\
\hline Hyperhidrosis & 1 & 127 & 538 & $23.6 \%$ \\
\hline Migraine-like Headache & 8 & 221 & 3006 & $0.03 \%$ \\
\hline Vertigo & 2 & 11 & 629 & $1.74 \%$ \\
\hline Alopecia/Telogen effluvium & 3 & 537 & 2313 & $23.21 \%$ \\
\hline
\end{tabular}




\begin{tabular}{|c|c|c|c|c|}
\hline Dyspnea & 15 & 790 & 3242 & $24.38 \%$ \\
\hline Anosmia & 13 & 497 & 3924 & $12.66 \%$ \\
\hline Dry eyes & 1 & 21 & 146 & $14.38 \%$ \\
\hline Blurred vision & 3 & 70 & 838 & $8.35 \%$ \\
\hline Dysgeusia/Ageusia & 7 & 293 & 3009 & $9.73 \%$ \\
\hline Arthralgia & 5 & 198 & 1211 & $16.35 \%$ \\
\hline Myalgias & 9 & 204 & 3527 & $5.78 \%$ \\
\hline Adjustment disorder & 1 & 2 & 355 & $0.56 \%$ \\
\hline Anxiety & 3 & 160 & 925 & $17.29 \%$ \\
\hline Dementia & 1 & 82 & 287 & $28.57 \%$ \\
\hline Dizziness & 3 & 123 & 2467 & $4.98 \%$ \\
\hline Depression & 2 & 117 & 825 & $14.18 \%$ \\
\hline Cough & 11 & 434 & 2527 & $17.17 \%$ \\
\hline Expectoration & 1 & 16 & 538 & $2.97 \%$ \\
\hline Insomnia & 6 & 725 & 2790 & $25.98 \%$ \\
\hline Obsessive compulsive disorder & 1 & 14 & 287 & $4.87 \%$ \\
\hline
\end{tabular}




\begin{tabular}{|c|c|c|c|c|}
\hline New-onset hypertension & 3 & 10 & 1180 & $0.84 \%$ \\
\hline New-onset diabetes & 2 & 3 & 642 & $0.46 \%$ \\
\hline Palpitations & 5 & 252 & 2952 & $8.53 \%$ \\
\hline Discontinuous flushing & 1 & 26 & 538 & $4.83 \%$ \\
\hline Restless leg syndrome & 1 & 2 & 355 & $0.56 \%$ \\
\hline Pedal edema & 1 & 14 & 538 & $2.6 \%$ \\
\hline Memory disturbances & 4 & 69 & 849 & $8.12 \%$ \\
\hline Rash/Cutaneous signs & 4 & 87 & 2417 & $3.59 \%$ \\
\hline Chest pain & 12 & 459 & 4422 & $10.37 \%$ \\
\hline Sore throat/odynophagia & 6 & 150 & 2886 & $5.19 \%$ \\
\hline Bowel/bladder incontinence & 1 & 8 & 100 & $8 \%$ \\
\hline Tinnitus & 1 & 48 & 287 & $16.72 \%$ \\
\hline Weight loss & 3 & 42 & 504 & $8.33 \%$ \\
\hline $\begin{array}{l}\text { Diarrhea/Vomiting/gastrointestinal } \\
\text { issues }\end{array}$ & 7 & 236 & 2911 & $8.1 \%$ \\
\hline More than one symptom & 5 & 456 & 1533 & $29.74 \%$ \\
\hline
\end{tabular}

Table 3. Post-acute COVID-19 signs and symptoms after recovery 


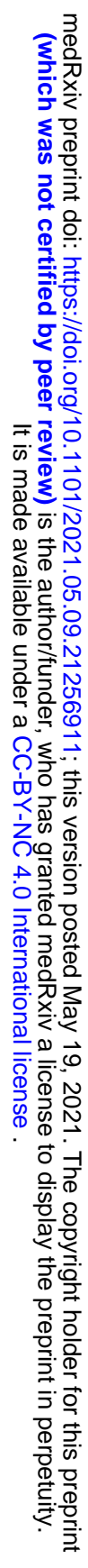




\section{LitCOVID (PubMed/Medline)}

December 2019 to March 2021

16,157 Citation(s)
CINAHL

December 2019 to March 2021 1,923 Citation(s)
Embase

December 2019 to March 2021 2,289 Citation(s)

\section{Web of science (excluding Medline)}

December 2019 to March 2021

1,372 Citation(s)

5,398 Non-Duplicate

Citations Screened

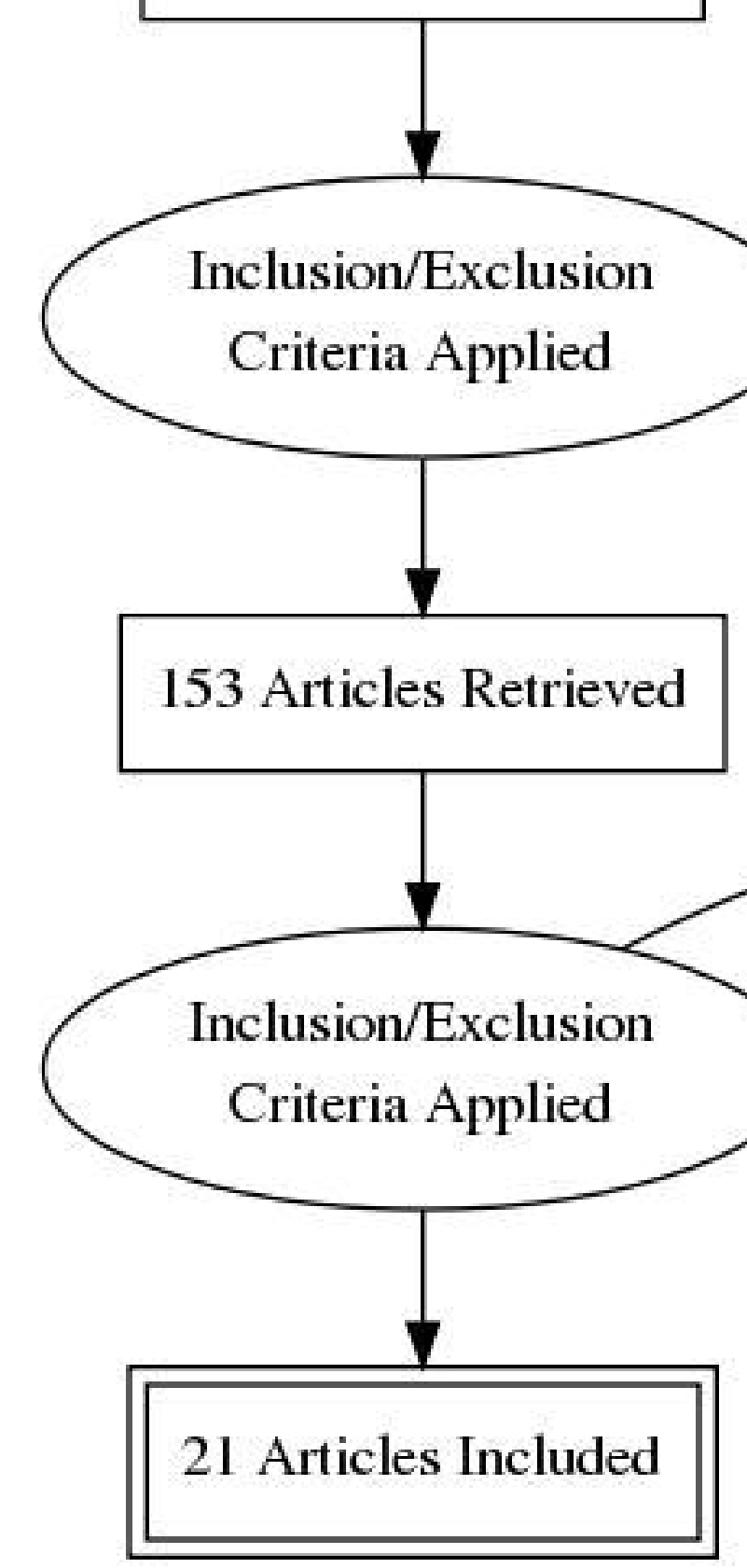

5,245 Articles Excluded

After Title/Abstract Screen

128 Articles Excluded

After Full Text Screen

4 Articles Excluded

During Data Extraction 